Kongunadu Arts and Science College, Coimbatore.

\title{
BIOMASS PRODUCTION AND OIL YIELD OF LEMONGRASS IN PUNALUR FOREST DIVISION, KERALA, INDIA.
}

\author{
Nisha Raj, S' ${ }^{1}$. S. Sekaran ${ }^{2}$, and S. Paulsamy ${ }^{3}$ \\ ${ }_{1}^{1}$ PG Department of Biotechnology, SAS, SNDP Yogam College, Konni- 689691, Kerala, India. \\ ${ }^{2}$ Department of Botany, Sree Narayana College, Kollam-691 001, Kerala, India. \\ ${ }^{3}$ Department of Botany, Kongunadu Arts and Science College, Coimbatore - 641 029, Tamil Nadu, India. \\ *E-mail: drsekhar72@gmail.com
}

\begin{abstract}
Lemongrass (Cymbopogon citratus) cultivation and oil distillation from its biomass are some of the important sources of earning for the rural people and tribal communities of sourthern Western Ghats in certain specific localities. Punalur Forest Division of Kerala is one such region where some local public involved in these practices. However, no data are available on the biomass production and oil yield of lemongrass for this region. Therefore, the present study has been carried out in this line. The results of the study reports that annual biomass production was greater $(9250 \mathrm{~kg} / \mathrm{ha} / \mathrm{yr})$ and comparable to that of the other lemongrass cultivated areas. Similarly, the oil yield was also higher $(46.7 \mathrm{~kg} / \mathrm{ha} / \mathrm{yr})$ and the concentration of oil varied significantly across the harvesting times $(0.43-0.63 \%)$. The statistical processing of data elucidates that soil $\mathrm{pH}$ and calcium content were having significant positive correlation to lemongrass biomass production. Oil concentration in the biomass was negatively correlated to relative humidity. Therefore, soil nutrient status can be considered as a key factor while preparing the management plan for lemongrass cultivation in Punalur Forest Division.
\end{abstract}

Keywords: Lemongrass, biomass production, oil yield, Punalur Forest Division, Kerala.

\section{INTRODUCTION}

Lemongrass (Cymbopogan citratus Stapf.) belongs to the family, Poaceae is a native aromatic tall sedge grass (Rangari Vinod, 2009) and has distributed in low hills of southern Western Ghats of Kerala and Tamilnadu in peninsular India. Due to its diverse medicinal values, it is being cultivated commercially in these regions for the past few decades. In Punalur Forest Division, Pathanamthitta district of Kerala state, at fragile ecosysytems in Western Ghats around 100-200m altitude, this grass is cultivated for oil distillation. Local people those involved in this practice are getting a sizable economic return also. However, no ecological data are available on lemongrass production status and oil yield for this grass in this region. Therefore, the present study was aimed at to obtain the data on biomass production and oil yield of lemongrass in Punalur Forest Division, Kerala.

\section{MATERIALS AND METHODS}

\subsection{Study area}

Punalur Forest Division situated in Pathanamthitta district, Kerala is mainly covered by teak plantation forests in addition to natural forests, comprising mainly Artocarpus sp. and Pterocarpus sp. The sloppy areas where the forests area cleared are used for the utilization of lemongrass by the people of local panchayath. The soil of the area is sandy loam with alkaline $\mathrm{pH}$ around 8.5. Climatic data of the study area was collected from Punalur Forest Division for the study period. The annual rainfall for the past 15 year's average is $1400 \mathrm{~mm}$. The temperature is varying between 20 and $39^{\circ} \mathrm{C}$ and the relative humidity was ranging between 61 and $91 \%$.

\subsection{Soil analysis}

Soil samples from $A_{1}$ layer $(0-10 \mathrm{~cm})$ collected during each harvesting time were mixed thoroughly to obtain composite sample. Working samples were obtained to analyze the soil for $\mathrm{pH}$ (Ghosh et al. 1983), total nitrogen (Jackson, 1962), available phosphorous (Bray and Kurty, 1945) and available potassium, calcium and magnesium (flame photometric method, Standford and English, 1949).

\subsection{Biomass production and oil yield}

An one hectare plot was established in the lemongrass community. Sampling for biomass was made 5 times in the study year, 2013-2014 when the farmers harvested the grass for oil distillation. The data on dry weight of lemongrass was collected from the farmers directly after harvested on hectare basis. Similarly, data on oil yield was collected from the 
farmers on hectare basis. As the grass was completely scraped during harvest, the biomass harvested at every time is its production. The biomass data collected for all the five harvesting times were added together to arrive the annual production (Singh and Yadhav, 1974).

\section{RESULTS AND DISCUSSION}

The variations in climatic and soil factors between the harvesting periods of lemongrass are present in Table 1. Both maximum and minimum temperatures were higher during April, 2014 (39 and $28^{\circ} \mathrm{C}$ respectively) and lower during January, 2014 (22 and $18^{\circ} \mathrm{C}$ respectively). As a general pattern, the rainfall during south-west monsoon (June - August, 2013) was higher $(810 \mathrm{~mm})$ in the study year which shared $58 \%$ in the total annual rainfall. The relative humidity was also higher during south-west monsoon period (90 - 91\%). The soil pH was always alkaline during the study period (8.0 8.5). The contents of soil nutrients such as N, P, K, Ca and $\mathrm{Mg}$ were also showed much variations between the sampling times $(\mathrm{N}-0.90$ to $1.10 \%, \mathrm{P}-0.05$ to $0.07 \%, \mathrm{~K}-0.25$ to $0.45 \%, \mathrm{Ca}-0.08$ to $0.14 \%$ and $\mathrm{Mg}$ - 0.02 to $0.04 \%$ ). All the climatic and soil factors studied were found to be more suitable for plant growth, particularly the lemongrass (Nambiar and Matela, 2012).

Biomass production of lemongrass in Punalur Forest Division was much varied across the periods of harvesting (Table 2). The growth of the lemongrass in the study area, Punalur was higher during August - November, 2013 as the biomass was greater during that period $(2600 \mathrm{~kg} / \mathrm{ha})$. The winter and summer months were characterized by less biomass of $1800 \mathrm{~kg} / \mathrm{ha}$ during January and $1200 \mathrm{~kg} / \mathrm{ha}$ during summer. It may be attributed to the fact that with the onset of monsoon in June, there was an active biomass build up and it attained maximum during August after two months of vegetative growth. Singh and Krishnamurthy (1981) reiterates that the temporal variation exhibited in the attainment of peak biomass in grassland communities of tropical climate is related to quantity of rainfall. Paulsamy et al. (2000) showed an enhanced biomass production of lemongrass at the end of south-west monsoon season in some parts of Anaimalais, the Western Ghats. The lemongrass production decreased progressively towards summer from August. It may be explained due to the influence of water as limiting factor. The total annual net primary production of lemongrass in the study area was estimated as $9250 \mathrm{~kg} / \mathrm{ha}$.

The percentage of oil in the lemongrass biomass was significantly varied between the sampling times (Table 2). Higher oil concentration of $0.63 \%$ was noted during summer and that of the lower $0.43 \%$ was during the rainy month of August, 2013. Oliveros and Aureus (1977) explained that the variation in oil content is the function of weather conditions like dry environment with higher incidence of sunlight which promotes the formation of such chemicals for resisting the adverse conditions.

Table 1. Climatic and soil factors of the study area, Punalur Forest Division during the samplings of lemongrass biomass.

\begin{tabular}{|c|c|c|c|c|c|c|c|c|c|c|}
\hline \multirow{4}{*}{$\begin{array}{l}\text { Year and } \\
\text { month }\end{array}$} & \multicolumn{4}{|c|}{ Climatic factors } & \multirow{2}{*}{\multicolumn{6}{|c|}{ Soil factors }} \\
\hline & \multicolumn{2}{|c|}{ Temperature $\left({ }^{\circ} \mathrm{C}\right)$} & \multirow{3}{*}{ Rainfall (mm) } & \multirow{3}{*}{$\begin{array}{c}\text { Relative humidity } \\
\text { (\%) }\end{array}$} & & & & & & \\
\hline & & & & & \multirow{2}{*}{ pH } & \multicolumn{4}{|c|}{ Nutrient conte it (\%) } & \multirow[b]{2}{*}{ Mg } \\
\hline & Max & Min & & & & $\mathbf{N}$ & $\mathbf{P}$ & $\mathbf{K}$ & $\mathrm{Ca}$ & \\
\hline \multicolumn{11}{|l|}{2013} \\
\hline Jun & 33 & 29 & 145 & 91 & 8.1 & 0.90 & 0.06 & 0.35 & 0.10 & 0.02 \\
\hline Aug & 31 & 28 & 665 & 90 & 8.3 & 0.95 & 0.05 & 0.30 & 0.12 & 0.03 \\
\hline Nov & 29 & 24 & 435 & 85 & 8.5 & 1.10 & 0.05 & 0.25 & 0.14 & 0.02 \\
\hline Jan & 22 & 18 & 80 & 70 & 8.0 & 1.05 & 0.07 & 0.35 & 0.10 & 0.03 \\
\hline Apr & 39 & 28 & 60 & 61 & 8.0 & 0.95 & 0.06 & 0.45 & 0.08 & 0.04 \\
\hline
\end{tabular}

Table 2. Biomass production and oil yield of lemongrass in Punalur Forest Division, Kerala.

\begin{tabular}{|c|c|c|c|}
\hline Year and month & Lemongrass biomass (kg/ha) & Oil concentration (\%) & Oil yield (kg/ha/yr) \\
\hline \multicolumn{4}{|l|}{2013} \\
\hline Jun & 1600 & $0.47^{a} \pm 0.05$ & 7.52 \\
\hline Aug & 2030 & $0.43^{\mathrm{a}} \pm 0.06$ & 8.82 \\
\hline Nov & 2600 & $0.51^{\mathrm{b}} \pm 0.05$ & 13.26 \\
\hline \multicolumn{4}{|l|}{2014} \\
\hline Jan & 1800 & $0.53^{\mathrm{b}} \pm 0.07$ & 9.54 \\
\hline Apr & 1200 & $0.63^{c} \pm 0.05$ & 7.56 \\
\hline Total a nnual production & 9250 & & 46.7 \\
\hline
\end{tabular}

*Mean followed by various letter for the column 'oil concentration' are significantly varied at 5\% level. 
Table 3. Correlation coefficient $(r)$ between the variables of lemongrass production and certain environmental factors in Punalur Forest Division, Kerala.

\begin{tabular}{|c|c|c|c|c|c|c|c|c|c|c|}
\hline \multirow{2}{*}{ Lemongrass production attributes } & \multicolumn{4}{|c|}{ Climatic variables } & \multicolumn{6}{|c|}{ Soil variables } \\
\hline & Ma.t & Mi.t & Rf & $\mathbf{R H}$ & pH & $\mathbf{N}$ & $\mathbf{P}$ & $\mathbf{K}$ & Ca & Mg \\
\hline Lemongrass biomass & -0.525 & -0.295 & 0.678 & 0.566 & $0.904^{*}$ & 0.707 & -0.565 & $-0.967^{* *}$ & $0.986^{* *}$ & -0.663 \\
\hline Oil concentration & 0.378 & -0.137 & -0.700 & $-0.926^{*}$ & -0.484 & 0.129 & 0.412 & 0.725 & -0.605 & 0.650 \\
\hline
\end{tabular}

relationships among the variables of lemongrass production (biomass and oil yield) and certain climatic and soil factors (Table 3). The soil pH and calcium content were significant positive correlation to biomass production $(r=0.904, P<0.05$ and 0.986 , $P<0.01)$. Similar kind of observations on the requirement of nutrients like Ca for better growth of Cymbopogon spp. was made already (Jayalakohmimituala and Mohanaraopuli, 2013; Singh et al., 2014). The level of alkalinity is reported to be a most preferable factor for the growth of lemongrass (Jayasinha et al., 1999; Paulsamy et al., 2000). Oil concentration in the biomass of lemongrass has no significant positive correlation to any environmental factors studied.

In Pearson's correlation, potassium content of soil was significant negative correlation to lemongrass biomass $(r=-0.967, P<0.01)$. The available potassium content in soil generally has inverse relationship with rainfall as this nutrient leaches out rapidly than any other elements in the soil by rain water percolation (Salisbary and Ross, 1991). Therefore, biomass enhancement was coupled with rain water and thus by negatively influenced by soil potassium content. The oil concentration in lemongrass was also has significant negative correlation to relative humidity of atmosphere $(r=-0.926, P<0.05)$. It is explained that it is a defence mechanism to produce more biochemical compounds including essential oils to resist high humidity for certain plant species (Castelo et al., 2012).

The present study clearly suggests that lemongrass production and oil concentration in biomass are the functions of soil factors like $\mathrm{pH}$ and calcium content but their intensity of influence vary according to other climatic variables like relative humidity and soil variables like potassium content. Therefore, the soil nutrient status can be considered as a key factor by preparing management plan for lemongrass cultivation in Punalur Forest Division, because rainfall is not a limiting factor in the landscape.

The authors acknowledge the UGC, Bangalore, India for providing financial support.

\section{REFERENCES}

Bray, R.H. and L.T. Kurtz, (1945). Determination of total, organic, and available forms of phosphorus in soils. Soil Sci. 59: 39-45.

Castelo, A.V.M., C.H.S. Del Menezzi and I.S. Resck, (2012). Seasonal variation in the yield and the chemical composition of essential oils from two Brazilian native abusive species. J. Appl. Sci. 12: 753-760.

Ghosh, A.B., J.C. Bajaj, R.Hasan and D. Singh, (1983). Soil and Water Testing Methods, Laboratory Manual. pp. 21-22. (ICAR Publication, New Delhi).

Jackson, M.L. (1962). Soil Chemical Analysis. Asia Publishing House, Bombay.

Jayasinha, P., D. Warnaswriya and H. Dissanayake, (1999). Medicinal and aromatic plant series. No. 9. Lemongrass survey. Information Service Centre, Industrial technology Institute, Colombo, Sri Lanka.

Nambiar, V.S. and H. Metala, (2012). Potential functions of Lemongrass (Cymbopogon citratus) in health and disease. Int. J. Pharmaceu. Biol. Arch. 3: 1035-1043.

Oilveros, B.L. and E. Aureus, (1977). Essential oil from (Cymbopogon citratus Stapf.) growing wild in Philippines. Perfume. Flavour. 2: 59.

Paulsamy, S., T.N. Rangarajan, K. Arumugasamy, S. Manian, K. Udaiyan, R. Sivakumar and D. Senthilkumar, 2000. Effect of habitat variation on the structure, herbage production and oil yield of Cymbopogon flexuosus Stapf. dominated grasslands in Anamalais, the Western Ghats. J. Environ. Biol. 12: 85 - 94.

Rangari Vinod, D, (2009). Pharmacognosy and Phytochemistry, Carrer Publication, Vol. $1^{\text {st }}, 2^{\text {nd }}$ ed. pp. 380-381.

Salisbury, F.B. and C.W. Ross, (1991). Plant Physiology. Wordworth Publishing Com., California, USA. pp. 682.

Singh, J.S. and L. Krishnamoorthy, (1981). Analysis of structure and function of tropical grassland vegetation of India. Indian Rev. Life Sci. 1: 225-270.

Singh, J.S. and P.S. Yadava. 1974. Seasonal variation in composition, plant biomass and net primary productivity of tropical grassland at Kurukshetra, India. Ecol. Monogr. 44: 351-375.

Stanford, S. and L. English (1949). Use of flame photometer in rapid soil test of K and Ca. J. Agro. 41: 446-447. 